\title{
COMMENTS ON RENEGOTIATION AND THE CONSTITUTION
}

\author{
、 MaLcolm P. Sharp*
}

W

HEN two such powerful forces as the love of gain and the passion of combat are at work, it is perhaps a little idle to ask just how they will express themselves in constitutional law. Renegotiation is one means of combining both impulses. The only disinterested criticism of the device comes from those who consider it part of a system to avoid the steep personal income taxes which would doubtless be the most effective safeguard against inflation. Businessmen, except at times in their own cases, have supported it as an alternative to heavier taxes and to flat (say six per cent) profit limitations. Substantial profits on moderate risks have been assured by renegotiation. The vitality and good name of the profit system are protected for the return of peace. Production of the materials and implements of war is stimulated by appeals to the profit motive, as well as by combative impulses and patriotism.

For gain is not the only incentive to either businessmen or soldiers in time of war. All the complex appeal of military enterprise and rivalry is at work, too.

When such objectives and motives are present, it may be supposed that arrangements which appear practical will rather easily be generalized into the law. Practical needs, or supposed practical needs, have affected the interpretation of the Constitution. This appears the more natural as we come increasingly to see in what broad and general terms the framers gave power to the national Government to which they intrusted "the purse and the sword."

The broad outlines of current economic and political history must thus of course be recalled in considering the place of renegotiation under the Constitution. At the same time, narrower considerations are relevant. It is of some importance that we keep some sense of continuity and security as we develop new institutions. The current adjustments will be easier and more intelligible if they are seen in relation to the familiar ideas of contract and constitutional law.

* Legal Reviewer, Price Adjustment Section, Chicago Ordnance District. The opinions expressed herein are those of the author. They are not to be taken as representing War Department policy. 
A number of situations may arise to test the Renegotiation Act under the Constitution. The simplest case is that of the prime contract formed after the enactment of the law. We have become so used to the view that the obligation of a contract is not impaired by a prospective law that we may say that such a situation presents no constitutional problem at all.

Yet this is not the case. In a different but somewhat comparable situation, some applicable considerations were advanced by Chief Justice Marshall. Senator Taft's shock at the enactment of the Renegotiation Act expressed itself in a statement that contracts had been abolished by the law. His reaction is a typical beginning of a constitutional argument.

Suppose, for example, that a Congress should enact a law providing that no undertaking in any subsequent act of the same Congress should be binding on the United States. Suppose then that war is declared and a scheme of war-risk insurance is provided by the same Congress. At a later time it appears that some of the provisions for insurance have turned out to be more generous than was anticipated. A later Congress, on the return of peace followed by a business depression, decides to save money. It modifies the terms of outstanding war-risk insurance term policies by making less liberal the provisions for renewal. The later enactment is challenged, by any appropriate method, as a denial of due process of law and a taking of private property for public use without compensation. Let us suppose, a not unlikely case, that the procedural difficulties in the way of presenting such a challenge are overcome. Can it be doubted that the later enactment would be held unconstitutional by any Court whose membership can now be anticipated?

A leading case dealing with a challenge to a state law operating prospectively under the Contract Clause was decided over the dissenting opinions of Chief Justice Marshall and Mr. Justice Story. New York, in the opening years of the nineteenth century, had taken a long step in the direction of what was then a novelty - a voluntary bankruptcy proceeding terminating in discharge of the debtor. Chancellor Kent was a member of a legislative committee that viewed such novelties with considerable alarm, but he had not ventured to hold legislation of this type unconstitutional. When the case was presented to the Supreme Court, the decision was in favor of the validity of the legislation. The ground of the decision has become an elementary principle of law. A prospective law enters into the terms of later contracts, and so does not impair their obligation. ${ }^{x}$

\footnotetext{
1 Ogden v. Saunders, 12 Wheat. (U. S.) 213 ( 1827 ). With the dissent in this case, compare Senator Taft's observations as reported in the press and in the Congressional Record for April 23, I942. See 88 Cong. Rec. $3774-76$ (I942).
} 
The principle is now elementary and is considered obvious; but it did not seem so to the two ablest lawyers on the bench. Mr. Justice Story, the learned lawyer's lawyer, and Chief Justice Marshall, the creative conservative, both thought that such a law did impair the obligation of contracts made after its enactment.

A contract, they said in effect, is a promise which can be enforced at law. There are many familiar limitations on the enforcement of promises. If they are against public policy or barred by a statute of limitations, or within the operation of statutes of frauds, undertakings which would otherwise be contracts cannot be enforced. Subject, of course, as it was to such definition, the classification of human relationships known as contract was reasonably well determined at the time the Constitution was ratified. Any law which deprives undertakings within that classification of their binding force must be said to impair the obligation of contracts. So the state statute which permits one who has incurred simple commercial debts to rid himself of those debts, on the concurrence of a fraction of his creditors, must be said to impair the obligation of contracts.

The argument of the dissenting opinions is closely related to the doctrines of freedom of contract and unconstitutional conditions which have prevailed in more recent decisions of the Supreme Court. Vary the terms to suit the words "liberty" and "property" in the Fifth Amendment, and the force of the theory is apparent. In an extreme instance of bad faith like the modification of war-risk insurance supposed, the result can hardly be in doubt.

Nor is the extreme case an unbelievable one. In fact, we have already had it in the form of retrospective legislation affecting first World War war-risk insurance, passed during the great depression as an economy measure. A unanimous Court speaking through Mr. Justice Brandeis held the retrospective legislation unconstitutional. ${ }^{2}$ The Court went far in intimating that it would insist at any opportunity that the Government provide some means for discharging its obligations on war-risk insurance. Administrative determination might be substituted for action in the Court of Claims, and sovereign immunity invoked, but the obligation to pay could not be avoided consistently with the Constitution.

The requirements of elementary good faith are insisted on in this opinion and were finally observed in the case. The difference between the case decided and the case of prospective legislation just supposed is trifling. The lapse of a short time between undertaking and repudiation might

2 Lynch v. United States, 292 U. S. 57 I (1934). 
make a situation created by prospective legislation even more flagrant than the case which actually occurred. There can be little doubt that a simple program of economy at the expense of holders of war-risk insurance would in any situation find little support from lawyers now likely to be appointed to the Supreme Court.

It will be observed that the war-risk insurance case was decided by the same Court which upheld what was in effect the repeal of the Government's obligation to pay gold to holders of government bonds. ${ }^{3}$ The Court did not put the matter this way, and the opinion in the gold clause case rested on the ground that bondholders could show no damage as a result of the Government's gold legislation. It is not necessary to resort to such refinements to discover a distinction between the war-risk insurance case and the gold clause case. The attempted modification of war-risk insurance contracts was simply a device to economize at the expense of the policyholders. The provisions of the devaluation legislation applicable to government gold bonds were a consistent if not indispensable feature of a general program for the purpose of combating nationwide deflation by familiar monetary measures. Just as an existing contract may be modified by state legislation in the interests of well-defined general policy under the authority of the so-called police power, so there can be no doubt that contractual obligations may be modified to some extent in the interests of well-defined general national policy, by congressional enactment.

Senator Taft is right in one respect. Even prospective legislation might conceivably go so far in destroying the reliability of government obligations that it would violate the Constitution. The prospective provisions of the Renegotiation Act cannot be justified simply on the ground that they operate prospectively. The act must be justified, if at all, in both its prospective and its retrospective operation, on the ground that while it may affect the terms of government obligations, it does so only in the interest of well-defined general national policy.

It does not seem difficult to justify the act as a whole on this ground. Procurement contracts have been made to a greater or lesser extent throughout the war under conditions which come close to warranting correction as a matter of common law. Prime contracts themselves give the Government privileges of termination, and the general pattern of procurement contracts reflects uncertainty about both the present and the future. The powers of the Government at war are in any case extensive. As an incident of purchasing, price standards need not be as clearly defined, for example, as tax standards.

3 Perry v. United States, 294 U. S. 330 (I935). 
The standard procurement contract entered into directly with the Government has been characterized by extraordinary flexibility. ${ }^{4}$ The first step may be a letter which authorizes the contractor to proceed, and undertakes on specific conditions to reimburse him for his costs. This instrument is followed in the ordinary course of events by a more elaborate writing. Here the Government typically reserves the right to change specifications and schedules, along with a sweeping privilege of termination for its own convenience. Again, on termination, reasonably generous provisions protect the contractor in recovering his costs. Termination provisions in effect for prime contracts and comparable provisions contemplated for the protection of subcontractors are part of a coherent scheme for distributing the risks of procurement contracts over the national community as a whole, and thus compensating contractors for the disadvantages of flexibility.

It is apparent that results comparable to renegotiation might have been reached at the time when the Renegotiation Act was passed, by the wholesale exercise of the Government's option to terminate prime contracts. In a large variety of transactions classified as subcontracts the result would have been simply to deprive subcontractors of orders to which they had no contractual rights. In other cases prime contractors had reserved a privilege to terminate subcontracts. In still other cases the practical consequence would have been negotiation between prime contractors and subcontractors for the modification of outstanding contractual undertakings. It seems likely that the hypothetical sweeping exercise of the Government's option to terminate prime contracts would have operated practically to terminate many subcontracts as well.

On termination, new contracts would, of course, have been entered into. In case of difficulty the Government had always the final weapon of the mandatory order. In April, I942, simple contractual machinery existed for the elimination of outstanding procurement contract claims and the substitution of new ones. It was obviously clumsy machinery, and the $\operatorname{Re}-$ negotiation Act produced the same result in much more elegant and practical form.

Quite apart from contractual privileges of modification and termination, procurement contracts entered into during these first months and years of our participation in the war have been subject to something of the same kind of infirmity as contracts entered into under mistake about

${ }^{4}$ See Fain and Watt, War Procurement-A New Pattern in Contracts, 44 Col. L. Rev. 126 (1944). This article provides the acquaintance with procurement which is indispensable to an understanding of renegotiation. 
either the present or the future. A mistake in arithmetic or in the tabulation of items may make a builder's accepted bid unenforceable. ${ }^{5}$ A railroad brakeman who settles for a personal injury, when both he and his employer assume confidently that his injury is a minor one, may avoid the settlement when it turns out that he is incapacitated for life. ${ }^{6}$ A steamship company which pays the supposed widow of a long-lost husband, on the assumption entertained by both parties that he was killed in a collision, may recover the payment on the discovery that it was another man with the same name. ${ }^{7}$ When seats were sold for the coronation procession for Edward VII and his illness delayed the ceremony, the owners of houses along the procession route were held to have no right to money which was to have been paid after the date first set for the procession. ${ }^{8}$ Last year the highest English authority went further, and held that in a comparable situation money paid before the date of performance could be recovered by the person who had paid. ${ }^{9}$ While a singer's estate might be liable to a theater owner, at least for part of his advertising expenses, it appears that there is no liability whatever at common law if a singer dies between the date of a contract and the time for performance. ${ }^{x 0}$

The clearly expressed and understood terms of an agreement may yield when the agreement is made in circumstances of uncertainty. Generally, indeed, the parties must be certain that the uncertainty does not exist, in order to get relief later from courts of equity or common law. They must be unconscious of the chances that they are taking and must indeed, as some of the cases can be read, act confidently on the assumption that no such contingency as in fact develops will take place. In a community occupied with normal commerce, risk and uncertainty bearing is one of the primary functions of contract. But even in such a society mistake about the present or the future may be so serious that a contract made under its influence will be recognized as a pathological case. Such a contract does not facilitate an intelligent distribution of cost or uncertainty, nor does it produce the beneficial effects supposed to come when wellinformed people arrange for the conduct of their own affairs.

${ }^{5}$ See 5 Williston, Contracts secs. I578-I579 (rev. ed. r937).

${ }^{6}$ St. Louis-San Francisco R. Co. v. Cauthen, II2 Okla. 256, 24I Pac. I88 (rg25) (alternative ground of decision). See 48 A.L.R. I447.

7 Grand Trunk Western R. Co..v. Lahiff, 218 Wis. 457 , 26I N.W. II (I935).

${ }^{8}$ Chandler v, Webster, [I904] I K.B. 493. See 6 Williston, Contracts, secs. I953-I954 (rev. ed. 1938 ).

9 Fibroso Spolka Akcyjna v. Fairbairn Lawson Coombe Barbour, Ltd., [r943] A. C. 32.

so Compare Taylor v. Caldwell, 3 B. \& S. 826 (Q.B. 1863 ). 
Somewhat different, but strictly comparable, considerations apply to an extemporized war economy and to legislation dealing with government contracts made in such an economy. Everyone has been conscious of the extraordinary uncertainties surrounding procurement contracts. These uncertainties have determined the flexible form of the contracts themselves. Repetition has dulled the force of the observation that wholly novel manufacturing and buying problems are presented in the procurement of the materials of war. Neither contractors nor War Department officials have had experience with the manufacture of combat planes and bombs on anything like the scale required for the purpose of this war. No one has been able to foresee the changes in requirements which occur as we pass in a recurring cycle from defense to offense and back again for a time to defense in different theaters of war. The reported shifts in German and Japanese concern with plane production, from bombers to fighters, are simply the most recent dramatic examples of the changes required by the shifting fortunes of war.

In procurement everyone concerned has been aware of the amount of uncertainty involved in planning production for military purposes. By ordinary commercial standards this might be a sufficient ground for denying relief for mistake or frustration in a court of equity or a court of law governed by judge-made precedents. Our traditional equity and common law rules have been criticized in some respects as unduly limiting relief for uncertainty, particularly uncertainty about the future. Uncertainty about the present, under the heading of mistake, has in some cases been handled with considerable liberality. Though a contractor is aware of the uncertainties which surround his transaction, these uncertainties may be so great as to make it impossible to work out any intelligent assumption of risk. Any arrangement the contractor makes may work out in an impractical way, because it is out of the question even to begin to calculate the possible permutations and combinations of circumstances which may occur. Under such circumstances a legislative and administrative program may quite properly go beyond the common law in relieving contractors and the Government from the consequences of uncertainty. Liberal provision has been made for contractors in the form of the regulations and practices governing Requests for Relief. The Renegotiation Act is a means of providing comparable relief for the Government. It does not go so far beyond common law principles, adjusted to suit the peculiarities of current enterprise, as to raise even a serious doubt about constitutional validity.

A number of narrow objections to such arguments may serve to bring 
out the character of the position advanced. It is sometimes said that manufacturers who continue to make their ordinary peacetime products and to sell these products under conditions like those of peace, sometimes to their regular customers, are not dealing under conditions in which wartime uncertainties play a peculiar part. The argument has been advanced, particularly on behalf of some subcontractors, that their contracts for standard products are practically like peacetime contracts, and are not infected with any peculiar degree of uncertainty. It is said to follow that the moral justification for renegotiation fails in such situations.

This does not seem to be the case. In such situations, where refunds are required it is usually because of an extraordinary increase in volume as compared with the contractors' peacetime base years. If contracting officers had enough knowledge and time, they could, presumably, insist on prime contract prices which would reflect savings that prime contractorsmight insist on in their transactions with subcontractors, in view of the enormous increase in volume which subcontractors have been enjoying. The refinements of the marginal-productivity theory may suggest diffculties with this argument. Here, as elsewhere in the field of renegotiation, it seems a sufficient answer to observe that the Government may properly treat all of a contractor's or subcontractor's war business as a unit. To say that a contractor or subcontractor might have done better in making money if he had expanded production somewhat less, and had chosen what war orders he would take, is no answer to the claims of a government which, by its war business as a whole, has given contractors and subcontractors unpredictable profits, as a result of the uncertainty, speed, and expansion which characterized procurement.

It may be said that, apart from mere mistake of expression, relief for mistake or frustration in contract law is commonly given by rescission, not reformation. A few groups of cases dealing with land contracts and conveyances are an exception to the general rule that, while the contracts which parties have made may be deprived of effect, they will not be remade by courts. As in the discussion of termination privileges, so here, the argument if followed would lead only to a rather clumsy treatment of the situation. Procurement contracts might be rescinded and new ones made. In that event the Government would still have the right, at any rate, by the exercise of a mandatory order to decide the terms of the new contracts. It is a short cut, and one to which patriotic contractors are ordinarily quite willing to agree, to arrange for flexible reconsideration of contracts already made, with the Government's extraordinary powers still unused but available. 
Again, it is sometimes urged as a defense against relief for mistake that a party has greatly altered his position on the faith of an existing arrangement. Where it is at all practicable, however, the fair treatment of such a situation seems rather to require fair compensation to the person who has altered his position, as a condition of giving relief to the other party. ${ }^{\mathrm{II}}$ As a condition of relief from mistake by renegotiation, if that is what occurs, the Government is required to compensate each contractor for his costs and to give him a reasonable profit on account of work done on the faith of a procurement contract. It seems certain that if the Renegotiation Act could in any case be so applied as to impair a contractor's right to such payments, it would be found that the contractor could derive legal protection from the Constitution. A requirement of elementary good faith would seem to protect the contractor, whether his transactions occurred before or after the enactment of the applicable provision of the Renegotiation Act, in his expectation of recovering his costs and securing a reasonable profit on the faith of his procurement contract.

It has been observed that the difficulties created by uncertainty have been increased by the necessity for speed. The demand for implements of war is both unpredictable and urgent. Under these circumstances contractors, habitually and inevitably concerned about their solvency, are in a strong bargaining position. They have every normal reason to guard their position carefully, and it is to their credit and the credit of all the contracting officers that they have moved fast and effectively. Yet the situation is one in which specialized experienced sellers dealing with an improvised set of buying agencies, staffed on the whole by men of less experience, have a great business advantage.

The essential contractor has a kind of legal duty to serve the Government. While this duty matures only on the use of a mandatory order, it seems proper to say that the obligation itself, or at least a significant legal relationship approaching the obligation, exists before the use of such an order. A threatened violation of this obligation might thus constitute duress in the most limited sense of the word. That is, it might be a violation of a legal right accompanied by powerful psychological pressure, like that produced by threats of violence or imprisonment, blackmail, or the withholding of badly needed property, or the threat of breach of contract under conditions threatening serious economic loss, in private cases. ${ }^{12}$

"x Paget v. Marshall, $28 \mathrm{Ch}$. D. 255, 267 (I884). Cf. Jones v. Waring and Gillow, Ltd., [1926] A.C. 670 , where the propriety of this treatment of mistake was recognized, though the case was held not to call for it. But compare Fibroso Spolka Akcyjna v. Fairbairn Lawson Coombs Barbour, Ltd., supra, note 9 .

${ }^{12}$ See 5 Williston, Contracts secs. I601-1608 (rev. ed. 1937). 
It is true that in a dubious case coming from the last war the Supreme Court has held that a contractor might go a long way in taking advantage of unskilled purchasers and the Government's need in exacting a high profit from war contracts. ${ }^{{ }^{3}} \mathrm{Mr}$. Justice Frankfurter's dissent, however, indicates persuasively how close to the line the case came. His argument is ample justification for legislation which has the effect of subjecting such contracts to revision at the election of the Government.

Generally, however, duress is not a word to describe the conduct of the great mass of patriotic contractors in this war. They are inevitably in a position of economic strength. If he is capable of producing urgent items, every contractor, regardless of his costs, is needed in the program. Each contractor is thus in a sense a monopolist, and he is likely to be free from the kind of check which competition affords even in a normal sellers' market. Competition cannot be looked for in the immediate future to give anything like the protection with respect to price and profits which the theory of the capitalistic system requires.

There is thus the same reason for introducing special safeguards which has justified minimum wage regulation and minimum or maximum price regulation in civilian industries under various circumstances. ${ }^{14}$ The Office of Price Administration cannot in the nature of the case serve the purpose, for its job is to set prices just high enough to give the needed marginal producer at least his costs. It is clear that the marginal war producer must have at least his costs and that his more efficient fellows, in their strong position, are not to have their price determined by his, on war contracts. With the speed properly required of procurement officers, it is thus plain that further supervision is in order. The reference to wage and price control should serve to indicate that on any assumption a workmanlike scheme of supervision is readily within the limits of an appropriate constitutional power.

The making and renegotiation of contracts for the materials of war is, of course, an exercise of the Government's war powers. These include the powers of Congress to raise and maintain a military establishment and to declare war, and the President's power as Commander-in-Chief of the armed forces. Today we do not need to be reminded how extensive these powers are. Yet there would hardly be an occasion for these comments if even these powers were not subject to constitutional limits.

${ }_{3}$ United States v. Bethlehem Steel Corp., $3{ }_{5} 5$ U.S. 289 (1942).

I4 Block v. Hirsh, 256 U.S. I35 (I92I); Levy Leasing Co. v. Siegel, 258 U.S. 242 (I922) (modification of existing contract rights by wartime rent legislation constitutional); Sunshine Coal Co. v. Adkins, 3ro U.S. 38I (r940); United States v. Darby, 312 U.S. 100 (I94I); Opp Cotton Mills v. Administrator, 3 I 2 U.S. т 26 (r94I). 
The flexible pattern of procurement contracts and the circumstances of uncertainty and pressure under which they are made mark them as appropriate for correction and supervision. There are, of course, other strongly positive reasons which justify the exercise of the war powers in eliminating excessive profits from operations under Government contracts.

Farmers, workers, and modest taxpayers, as well as managers and owners, have been called on to carry economic burdens resulting from the war. A fair distribution of burdens and benefits is to be desired in any case. A scheme which commends itself generally as fair is in the interests of those who are concerned with maintaining a strong and popular system of competitive capitalism through the stresses of war and the adjustments of a postwar period.

More immediately, the control and moderation of inflationary influences is necessary to the prosecution of the war itself. Whatever the importance of the dollar amounts involved in renegotiation, an example of self-control on the part of business leaders is essential, if the more poorly paid members of the community are to moderate their demands for compensation adjusted to a price level which is almost bound to rise to a greater or less extent. Control of inflation is a proper object for the exercise of the Government's fiscal and war powers.

Even more important, as has been pointed out, is the maintenance of fighting spirit in both the ununiformed and the uniformed forces. The profit motive may with some difficulty be combined with warlike enterprise, but it must inevitably be eclipsed by other motives in a successful war. The preservation of a relatively high degree of harmony, unity, and esprit de corps is promoted by the limits on war profits necessary to satisfy the national conscience. The development of appropriate limits seems on this ground a proper exercise of the war powers.

In the end, of course, the simplest form of statement takes us back to the boys who enlist or are drafted. Whatever the technical difficulties, no one has suggested a moral or constitutional objection to the drafting of capital as well as men. The soldier and the civilian alike have constitutional rights, but their normal civil rights may be closely restricted in the interests of the military effort.

This is not to say that unnecessary restrictions should be lightly acquiesced in. The sane treatment of freedom of expression in this war seems to some who recall the restrictive measures of the last war to have improved morale. Workers, managers, and owners alike are engaged in the 
struggle to maintain free institutions. The fewer the interferences with such institutions as freedom of contract, the better.

Unwarranted and extreme interferences with economic liberty, even in wartime, may meet a constitutional limit. Yet we have needed only an elementary recapitulation of familiar observations to remind ourselves of the limits to which economic activity is properly subject in wartime. There can be little doubt that in view of its moderate interference with contract rights and its function as an appropriate feature of wartime control, the Renegotiation Act is a proper exercise of the fiscal and military powers of the federal Government.

One difficulty remains to be considered. An old and sound instinct has expressed itself in much of the controversy over delegation of legislative powers to executive and administrative officials. Democracies have tired at times in Western history and turned over their powers to a strong man or group of men.

Yet it is doubtful whether the text of our Constitution affords any adequate basis for an effective limit on the delegation of legislative powers in domestic affairs. Specific provisions prohibit Congress from deciding to abolish elections and adjourn indefinitely. Yet, in spite of the Schechter case, ${ }^{x_{5}}$ Congress must, and therefore may, in many cases give general and even vague directions with respect to policy, leaving it to be implemented by administrative regulations and decisions.

The directions in the original Renegotiation Act to eliminate excessive profits were indeed vague. Some historical content could be derived from parallels in the excess profit tax legislation, and these parallels have proved useful. Terms in that legislation, however, could hardly be treated as incorporated by reference into the Renegotiation Act.

It should be recognized clearly that the Renegotiation Act is in no proper sense a tax measure; and when this has once been noticed the problem of the legislative standard seems to become easier. No government short of heaven will be able to finance itself by paying out large sums to individuals and taking back portions of those sums. The Renegotiation Act cannot possibly be viewed as anything like a revenue-raising measure. It cuts expenses, but it does not raise net amounts. However debatable the effect of renegotiation on later price structures, the Renegotiation Act cannot be classified as anything but a pricing statute. It is designed to decrease the amount of money paid by the Government for war goods.

It has never been supposed that legislation authorizing disbursements or even loans was subject to the same requirement of a legislative standard

${ }^{25}$ Schechter Poultry Corp. v. United States, 295 U.S. 495 (1935). 
as that which has been thought to apply to regulatory and particularly to criminal statutes. It may be said that no one has a "right" to any particular price on what he sells to the Government. It would perhaps be more realistic to say that Congress has not been accustomed always to set "standards" for government pricing. Purchasing agents must act honestly and fairly, and they must commonly follow prescribed procedures, but price policy, particularly in war times, has in many situations been left largely to administrative determination.

General statements are thus enough in legislation authorizing purchasing and giving directions about the terms on which purchases are to be made. The phrase "excessive profits" is perhaps indeed no more vague than some of the directive phrases which have been held to satisfy the requirement that Congress shall not delegate its powers without setting a standard for administrative officers. ${ }^{16}$

Certainly the phrase has not proved so meaningless as to leave the agencies administering the act without any intelligent guidance. It has proved possible to develop general directions which are at the same time by no means meaningless or ineffectual. A reading of renegotiation reports will doubtless disclose instances of inconsistencies, but it will also disclose a continual reference back to a list of relevant factors which limits the arbitrary discretion of the individual officer. The appearance of a list of guiding principles in the revised act indicates at once how administrative conduct has, bit by bit, come to be described and guided in general terms, and how easy it is completely to satisfy any kind of constitutional requirement of an administrative standard in the delegation of legislative powers.

Political judgments which seek expression in constitutional law may be sound in this as in other respects; but it does not follow that they can be served by any available constitutional doctrine. The sporadic appearance of decisions requiring Congress to set a standard in delegating its power may moderate somewhat tendencies toward executive rule in domestic matters. How little the formula can affect the general outlines of social and political history becomes apparent at once when one looks at the conduct of our foreign affairs. The Schechter case ${ }^{\mathrm{x} 7}$ stands in sharp contrast to the Curtiss-Wright case. ${ }^{{ }^{8}}$ Congress is expressly given the power to declare

${ }^{16}$ New York Central Securities Corp. v. United States, 287 U.S. I 2 (I932).

${ }^{17}$ Supra note 15.

${ }^{8} 8$ United States v. Curtiss-Wright Export Corp., 299 U.S. 304, 319 (I936). Speaking through Mr. Justice Sutherland, the Court considered the President's powers in external 
war under the Constitution, and the Senate's part in treaty-making is assured by a provision which is explicit and intelligible. Yet the Court has said that the President may properly exercise general and ultimate control over our foreign relations.

We are familiar with the extent to which the Executive has gone in the exercise of control and leadership in foreign affairs. The conduct of war inevitably leads to extended executive control in domestic matters. It is doubtful whether any traditional constitutional doctrine of delegation could properly have been extended to limit Congress and the President in domestic matters. Certainly no such doctrine is to be looked for now. The conclusion is that private rights have not been seriously modified by the Renegotiation Act and that such modifications as have been made were in the exercise of the war powers of Congress and the President. The authority delegated to administrative agencies by the act has been sufficiently defined for constitutional purposes.

affairs. "In this vast external realm, with its important, complicated, delicate and manifold problems, the President alone has the power to speak or listen as a representative of the nation." See also United States v. Pink, 3드 U.S. 203, 228-230 (1942). 